\title{
如何在小学语文教育教学中渗透德育教育
}

钟锐娟

广东省廉江市车板镇中心小学

DOI:10.32629/jief.v2i6.1100

[摘 要] 在小学语文教育中, 随着素质教育思想的不断开展, 教师不仅需要对学生进行语文知识教学, 还要让学生受到良好的德育教育, 因 此, 教师要将德育教育尽可能的融合进日常的教学工作当中, 让学生从知识与思想道德方面全面提升。本文对小学语文的教育如何渗透德育 教育进行分析，为小学语文教育工作者提供参考。

[关键词] 小学语文; 教育教学; 教学渗透; 德育教育

中图分类号: G633.3 文献标识码: A

在现代化教育中, 学校开始对学生的德育教育重视起来, 在日常知 识教学过程中融合了德育教育, 而语文教学在德育教育方面有着天然的 优势, 为引导学生能够有正确的道德价值观, 小学语文教育无论是学科 还是教学理念, 都要将德育教育渗透其中, 使学生能够从语文学习中潜 移默化的受到影响。因此, 语文教师在重视课程知识教学的同时, 也要 有效的进行德育教育。

\section{1 利用教材渗透德育教育}

语文教材作为小学语文教学的基础, 多式多样的课文以及丰富多彩 的插图都有着德育教育的内容, 因此小学教师要通过对课本内容与德育 教育相互融合, 制定教学大纲, 通过对教材内容的理解, 来制定针对德 育教育的教学内容。例如在人教版小学语文三年级下册中的《亡羊补牢》 这一寓言故事, 其中就体现了及时发现错误及时改正错误的重要性的道 理, 首先通过学生对故事的阅读, 配合课文插图进行自我理解, 教师根 据学生的心理特点, 对其中插图先做分析, 从破了洞的羊圈, 到羊被狼 偷走, 再到补上破洞的羊圈, 对学生进行引导分析, 先提起学生学习的 兴趣, 让学生首先对将要学习的东西有个大致的认识。然后再引领学生 对故事进行阅读分析, 其中的养羊人羊圈破洞丢羊而不听街坊邻居劝告 又丢羊, 再到补上羊圈羊再也没丢过, 给学生进行讲解, 让学生能够感 悟到犯错误不可怕, 可怕的是不听劝告不及时改正, 只要及时改正还不 会迟, 从而教会学生知错就改, 提升学生的道德思想水平。

\section{2 课外阅读渗透德育教育}

语文教学中, 除了教材内容外, 教师还可以通过课外内容对学生进 行引导, 在引入课外读物时, 教师要对内容进行严格笁选, 选择学生能 够理解的, 适合学生需求的读物, 结合学生的兴趣爱好与阅读习惯, 利 用具有德育教育价值的课外文章, 对学生进行意志品质的培养。在进行 课外阅读时, 教师要对学生进行相应的引导, 教会学生阅读方式, 激发 学生的阅读兴趣, 使学生在课外阅读中能够通过自行评价与欣赏获取其 中寓意。例如教师可以带领学生对《井底之蛙》进行阅读, 其中青蛙坐 在井底看着井口以为自己看到了整片天, 但是其实整片天一望无际。教 师引导学生对这篇文章进行理解, 告诉学生, 所处的位置决定着你的眼 界, 而不能因为自己看到的就确定那是全部, 只有不断地往上走才能够 看到更广阔的天空。在进行理解后引导学生进行反思, 在自己站的位置 看整个世界是不全面的, 要站在不同位置不同高度看世界才能有所了解,
让学生知道只有站的越高看的才能越远。从而使学生更好的学习, 为站 的更高。从思想上对学生进行提升培养。

\section{3 生活实践活动渗透德育教育}

学生的学习情况与德育教育的情况都是在现实生活实践中能够反映 出来的, 因此在进行语文教学时, 也要将课内课外相互关联起来, 使在 课本中学习的知识能够用与实践相互促进。所以, 教师可以以课本内容 为基础展开课外活动, 让学生能够通过课外活动加强巩固教学效果, 并 将德育教育落实进生活中。例如在《雷锋叔叔, 你在哪里》课文中, 在 血红色这个学习了解雷锋精神的同时, 教师可以组织学生发现现实生活 中的雷锋精神, 比如维持秩序的志愿者、路边献血车中的义务献血者, 主动摆放共享单车的人, 他们都是现实生活中的 “雷锋叔叔”, 还可以举 办争做小雷锋活动, 比如在生活中为养老院中的老人表演节目, 与老人 进行游戏, 帮助清洁工人清洁花园等, 让学生在实际活动中切身体会雷 锋精神, 学习奉献爱心、乐于助人的精神, 在进行活动中, 学生帮助他 人的同时也能够使自己的道德受到感染，从中感受帮助他人所获得的自 豪感与成就感, 从而使学生从心里层面提升自身的道德感悟与综合修养。

\section{4 结语}

综上所述, 在小学语文教育工作中, 将德育教育渗透其中是很有必 要的。通过语文教学, 对学生进行道德教育, 使学生在学习文化知识同 时也能够提高自身的道德意识。通过将德育教育渗透入语文教学的不同 方式中, 用先进的教学方式, 以及先进的教学理念, 让学生能够健康成 长。小学生的道德观, 价值观, 还没完全形成, 因此, 这其中语文教师 必须发挥出自己的教学智慧, 在小学德育教育工作方面对学生进行积极 的引导, 让学生从小接受真善美的教育, 树立正确的核心价值观, 具有 良好的道德素质，才能够提升学生的综合素养。

\section{[参考文献]}

[1]程军.基于小学语文主题教学实践的方法与策略研究 [J].新课 程,2020(38):6

[2] 郭子豪.提升语文课堂教学效率, 降低学生学习压力[J].新课 程,2020(38):8.

[3]周小丽.小学语文作文教学中层递式教学模式的应用探究[J].新 课程,2020(38):29. 